\title{
A magnesium-binding nucleotide, a remodeling ATPase, and a wonderful RNA world
}

\author{
REN-JANG LIN \\ Beckman Research Institute of the City of Hope, Duarte, California 91010, USA
}

Flipping through the first issue of $R N A$, two things specifically attracted my eyes: the original edition of The RNA World by Gesteland and Atkins, and a paper by Yi-Tao Yu et al. That classic monograph collected invaluable commentaries and reviews on the whole spectrum of RNA research from the legends and pioneers, on which I often relied for wisdom and insight. That paper by Tim Nilsen's group describing a phosphorothioate substitution study of U6 snRNA in nematode, and along with a similar study in yeast U6 by John Abelson's group, provided early chemical evidence that the bulging uridine ( $\mathrm{U}_{69}$ in nematode and $\mathrm{U}_{80}$ in yeast) at the $3^{\prime}$ stem-loop of the U6 snRNA is likely an essential catalytic constituent of the spliceosome. Following on those observations, Shyue-Lee Yean, a postdoc in my lab, spent a good three to four years trying to find answers to a simple question: which comes first, the phosphorothioated U6 block or the Prp2 step?

At that time Jean Beggs's and my groups have shown that Prp2 is an RNA-dependent ATPase that is required for the onset of splicing in the assembled spliceosome. We knew that the ATP hydrolysis by Prp2 induces a conformational rearrangement of the spliceosome that proceeded catalysis. Would phosphorothioated $\mathrm{U}_{69} / \mathrm{U}_{80}$ inhibit the spliceosome activation step by Prp2? Shyue-Lee initially synthesized the U6 RNA using polymerase incorporation of the modified nucleotides, but the imprecision of the $3^{\prime}$ ends and low yields forced him to use ligase to stitch together chemically synthesized RNA fragments. Luckily with the help from John Termini's group we not only made the $R_{\mathrm{P}}$ stereoisomers but also the $S_{\mathrm{P}}$ isomers. The experiments not only answered our initial question-modified U6 does not block the Prp2 step-but also uncovered an unanticipated, magnesium coordinating, and catalytically relevant activity of $\mathrm{U}_{80} S_{\mathrm{P}}$. With recent elegant works by the groups of Joe Piccirilli and Jon Staley (in addition to the structural work by the groups of Sam Butcher and Dave Brow) we now know that $\mathrm{U}_{80}$ indeed participates in catalytic metal coordination along with additional nucleotides of U6, and that the spliceosome is indeed a ribozyme. As for Prp2, through the effort of the groups of Soo-Chen Cheng and Reinhard Lührmann, among others, we now know that the

Corresponding author: RLin@coh.org

Article and publication date are at http://www.rnajournal.org/cgi/doi/10. 1261/rna.050336.115. Freely available online through the RNA Open Access option.
ATP hydrolysis by Prp2 leads to reshuffle several proteins onto or off the spliceosome, explaining the "down-sizing" of the spliceosome by Prp2 that we observed almost two decades ago. A sequence between the branchpoint and the $3^{\prime}$ splice site is critical for productive Prp2 action; however, whether U6 snRNA is involved in this remains unclear.

By working on yeast and human splicing factors, I found that not only human factors have more features but also the human cells have more complex responses to splicing perturbations. This is really nothing new; however, it reminds me of the conversation that I had with my musician daughter. She said that different music (classical, jazz, blues, etc.) has different building blocks as well as ways to arrange them; only with an understanding of that structure will a person be able to appreciate the meaning of that music (other than just a feeling). I wonder, although all biological systems have similar or conserved rules, some systems may predominantly use certain types of rules while others rely more on different ones. We have seen some intriguing examples for this in RNA biology_piRNA, RNA-dependent RNA polymerases, RNA-mediated transcriptional silencing, etc. Shall we be surprised if there are more-grand or subtle-to be found?

In the midst of organizing and teaching an advanced graduate course on RNA, I found that over two-thirds of the course dealt with topics that were just or not even discovered when $R N A$ was first published. Marvelously, those topics (microRNA, long non-coding RNA, CRISPR RNA, etc.) attract students to the RNA field and create a common language among colleagues from different fields. A legend and recombinant DNA guru in our institution had predicted that the past 50 years of DNA-focused research would give way to RNA-focused research. I am afraid that he is right, again.

I would like to thank Tim Nilsen for the opportunity to share these few thoughts with the RNA readers. Although I cannot predict where RNA research is heading, I fully anticipate many new discoveries and excitement regarding RNA will continue in the next 20 years and beyond, so long as we remain curious and keep exploring (with generous supports from funding agencies).

(C) 2015 Lin This article, published in RNA, is available under a Creative Commons License (Attribution-NonCommercial 4.0 International), as described at http://creativecommons.org/licenses/by-nc/4.0/. 

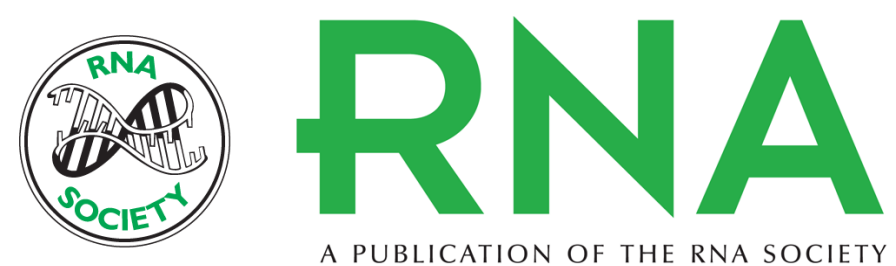

A PUBLICATION OF THE RNA SOCIETY

\section{A magnesium-binding nucleotide, a remodeling ATPase, and a wonderful RNA world}

Ren-Jang Lin

RNA $201521: 680$

Open Access Freely available online through the RNA Open Access option.

Creative This article, published in RNA, is available under a Creative Commons License

Commons (Attribution-NonCommercial 4.0 International), as described at

License http://creativecommons.org/licenses/by-nc/4.0/.

Email Alerting Receive free email alerts when new articles cite this article - sign up in the box at the Service top right corner of the article or click here.

To subscribe to RNA go to:

http://rnajournal.cshlp.org/subscriptions

(C) 2015 Lin; Published by Cold Spring Harbor Laboratory Press for the RNA Society 